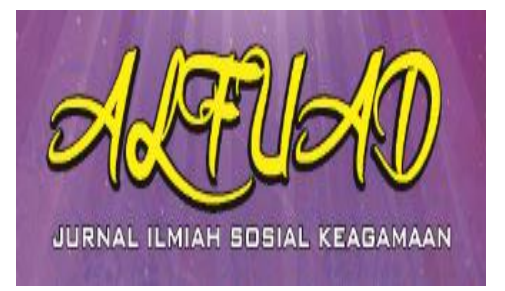

ALFUAD JOURNAL, 2 (2), 2018, (72-82)

(Print ISSN 2614-4786)

Available Online at

http://ecampus.iainbatusangkar.ac.id/ojs/index.php/alfuad

\title{
PENGARUH PENERAPAN PRINSIP GOOD CORPORATE GOVERNANCE (GCG) TERHADAP PENINGKATAN KUALITAS PELAYANAN DI PT BANK BTPN TBK CABANG PADANG
}

\section{Dewi Dahlan}

Institut Agama Islam Negeri Batusangkar Indonesia

E-mail: dewidahlan@iainbatusangkar.ac.id

\begin{abstract}
This study aims to determine the effect of the principles of good corporate governance (GCG) in this case transparency, accountability, responsibility, independence, and fairness towards service quality at the Padang branch of PT Bank BTPN Tbk. The results of this study indicate that Good Corporate Governance (GCG) (X) has a significant effect on the Service Quality of Padang Branch BTPN Banks (Y). The contribution of Good Corporate Governance (X) to Service Quality $(Y)$ is $79.9 \%$ and found to have a significant effect, while the remaining $20.1 \%$ is another factor not examined. The most powerful dimension of correlation is transparency with a correlation value of 0.896. All dimensions of service quality including tangible, reliability, responsiveness, assurance, and empathy have a strong correlation with Service Quality (Y), and are significant. The strongest correlation dimension is Reliability with a correlation value of 0.900 .
\end{abstract}

Keywords: Good Corporate Governance, Service Quality

\section{PENDAHULUAN}

Penerapan dan pengelolaan good corporate governance (GCG) merupakan sebuah konsep yang menekankan pentingnya hak pemegang saham untuk memperoleh informasi dengan benar, akurat, dan tepat waktu. Oleh karena itu, baik perusahaan publik maupun tertutup harus memandang GCG bukan sebagai aksesoris belaka, tetapi sebagai upaya peningkatan kinerja dan nilai perusahaan. (Sam'ani, 2008).

Kajian mengenai GCG meningkat dengan pesat seiring dengan terbukanya skandal keuangan berskala besar seperti skandal Enron, Tyco, Worldcom, Merck, Global Crossing mayoritas perusahaan lain di Amerika Serikat (Cornett, Marcuss, Saunders dan Tehranian, 2006) yang melibatkan akuntan, salah satu elemen penting dari GCG. Beberapa kasus yang terjadi di Indonesia, seperti PT. Lippo Tbk dan PT. Kimia Farma Tbk (Boediono, 2005) juga melibatkan pelaporan keuangan (financial reporting) yang berawal dari terdeteksi adanya manipulasi (Boediono, 2005). 
Di era globalisasi ini dengan semakin beraneka ragam pelayanan maupun jasa yang dibutuhkan masyarakat dan semakin ketatnya persaingan, maka Badan Usaha Milik Negara (BUMN) maupun Badan Usaha Milik Swasta (BUMS) harus mencari sistem yang paling efektif dan efisien dalam meningkatkan kualitas pelayanan. Untuk menciptakan pelayanan yang baik dan berkualitas kepada masyarakat sudah saatnya perusahaan-perusahaan di Indonesia menerapkan GCG dalam pengelolaannya. Salah satu bank swasta yang menerapkan prinsip GCG dalam meningkatkan kualitas pelayanannya adalah PT Bank BTPN Tbk. Secara sederhana $G C G$ dapat digambarkan sebagai bentuk pelaksanaan tanggung jawab antara perusahaan sebagai badan hukum, direksi, dan komisaris sebagai pengurus dengan para pemegang saham.

Berdasarkan hasil observasi awal Bank BTPN merupakan bank milik Sumitomo di bawah naungan Jepang yang melakukan fungsi manajemen dengan cara mengembangkan market share, membangun relationship dengan pihak ketiga, dan melakukan koordinasi dengan wilayah untuk menjalin hubungan dengan mitra. Market share inilah yang salah satunya menjadi landasan pelayanan bagi BTPN. Bank BTPN memiliki berbagai bidang usaha yaitu bisnis pensiun, syariah, usaha mikro dan pengumpulan dana (funding). Market share yang paling besar penjualannya adalah market bisnis pensiun (business pension). Oleh sebab itu pelayanan kepada nasabah yang merupakan calon dan pensiunan dari sipil, TNI, Polri, serta BUMN menjadi target utama pelayanan.

Berdasarkan laporan tahunan 2010 Bank BTPN, pelaksanaan tata kelola perusahaan yang baik merupakan faktor penting untuk menjamin pencapaian kinerja dan keberlangsungan usaha yang berkelanjutan. BTPN senantiasa menekankan pentingnya prinsip-prinsip etika dan moral serta budaya keterbukaan sesuai dengan ketentuan yang berlaku. Seluruh Dewan Komisaris, Direksi dan karyawan BTPN berkomitmen untuk melaksanakan prinsipprinsip tata kelola yang baik dalam setiap kegiatan perbankan. Perilaku usaha dari setiap insan BTPN dilandasi oleh pedoman perilaku dan etika, yang wajib ditandatangani oleh seluruh Dewan Komisaris, Direksi dan karyawan. Praktek tata kelola BTPN dilandasi oleh prinsipprinsip dasar pertama akuntabilitas, yang mencakup kejelasan tanggung jawab dan peran dari setiap posisi dalam organisasi BTPN. Kedua tanggung jawab, yang menekankan kepatuhan sepenuhnya pada peraturan dan ketentuan yang berlaku, dan komitmen menjadi anggota masyarakat yang bertanggung jawab pada lingkungan sekitarnya. Ketiga transparansi guna menjamin keterbukaan informasi material secara jelas, akurat dan tepat waktu. 
Keempat independen, yang mengedepankan obyektivitas dalam semua hal dan keputusan. Kelima kesetaraan yang menjamin perlakuan yang adil dan setara bagi setiap individu berdasarkan asas profesionalisme yang obyektif, serta menjamin perlakuan yang adil dan setara bagi setiap pemegang saham. Pelaksanaan prinsip-prinsip tata kelola perusahaan yang baik (GCG) merupakan hal yang sangat penting bagi Bank BTPN untuk mengembangkan bidang usahanya. Dalam penelitian ini yang akan dikaji adalah pengaruh GCG terhadap kualitas pelayanan di PT Bank BTPN, tbk Cabang Padang.

Sebagai upaya untuk memenuhi salah satu prisnsip $G C G$, BTPN mengadakan telah public expose pada 24 Oktober 2013, di ball room Hotel Intercontinental Jakarta. Pada acara tersebut dipaparkan apa saja penghargaan yang diterima BTPN dari berbagai lembaga, baik nasional maupun Internasional. Penghargaan tersebut antara lain Bank Terbaik dengan Modal Inti Rp. 5 Triliun sampai dengan Rp. 30 Triliun dari Tempo Media Group dan Center for Risk Management, Peringkat 1 "Anugerah Perbankan Indonesia 2013” Kategori Finance dengan modal inti Rp. 5 Trlilun sampai dengan Rp. 30 Triliun dari Majalah Economic Review dan Perbanas, masuk peringkat kedua terbaik dalam Hubungan Investor oleh Asiamoney Corporate Governance Poll 2012, serta kembali meraih peringkat tertinggi dalam "Rating 120 Bank" versi Infobank 2013. (Corporate Communication Bank btpn).

Secara singkat terdapat lima prinsip GCG, yaitu transparancy, independence, accountability, respon-sibility, dan fairness. Hal ini sejalan dengan Pedoman Umum Penerapan Good Corporate Governance yang diterbitkan oleh Komite Nasional Kebijakan Governance (KNKG) tahun 2006 dimana setiap perusahaan harus memastikan bahwa asas GCG diterapkan pada setiap aspek bisnis dan di semua jajaran perusahaan. Asas GCG yaitu transparansi, akuntabilitas, respon-sibilitas, independensi serta kewajaran dan kesetaraan diperlukan untuk mencapai kesinambungan usaha (sustainability) perusahaan dengan memperhatikan pemangku kepentingan (stakeholders). Melalui penerapan prinsip GCG, diharapkan menjadi kontrol terhadap pertanggungjawaban mengelola perusahaan. Dan dengan adanya penerapan GCG ini merupakan salah satu langkah penting bagi Bank BTPN tbk untuk meningkatkan dan memaksimalkan nilai perusahaan (corporate value) serta mendorong pengelolaan perusahaan yang professional melalui kualitas pelayanan.

Bagi bank BTPN dengan menerapkan prinsip GCG akan memberikan pengaruh yang sangat besar terhadap kualitas pelayanan. Aksi-aksi kecurangan atau penggelapan, termasuk pembobolan rekening nasabah di bank akan mendapat sanksi yang 
tegas. Perbuatan yang termasuk dalam kecurangan adalah perbuatan korupsi/ manipulasi, pencurian atau pembobolan rekening nasabah bank (deposito, giro, tabungan, dll.), penggelapan, pemalsuan, penipuan, suap-menyuap, pemerasan dan berbagai macam perbuatan melawan hukum lain yang merugikan keuangan perusahaan/ negara. Kasus-kasus kecu-rangan yang terjadi memungkinkan sebuah institusi perbankan (bank) tak hanya mengalami kerugian secara finansial, tetapi juga secara reputasional yang akan mempengaruhi kepercayaan dan mengakibatkan penurunan kualitas layanan terhadap masyarakat. Tentunya hal ini akan mempengaruhi kepercayaan masyarakat dan regulator terhadap bank yang bersangkutan. Pelayanan adalah suatu kegiatan yang terjadi dalam interaksi langsung antara seseorang dengan orang lain atau mesin secara fisik, dan menyediakan kepuasan pelanggan. (Ekky Dwi Ferlinda, 2013).

Menurut Parasuraman (1985) yang memperkenalkan konsep Service Quality (Servqual) secara ringkas menyatakan bahwa kualitas pelayanan merupakan fungsi harapan pelanggan pada tahap pra pembelian, proses penyediaan kualitas yang diterima dan kualitas output yang diterima. Parasuraman et al. (1985) mendefinisikan kualitas pelayanan (servqual) sebagai suatu konsep yang secara tepat mewakili inti kinerja suatu jasa, yaitu perbandingan terhadap keterandalan (excellence) dalam service counter yang dilakukan oleh pelanggan. (Juzan Tri Hartanto, 2010)

Dalam hubungannya dengan pelayanan, mekanisme pengelolaan perusahaan yang baik akan meningkatkan kualitas pelayanan di suatu lembaga dalam hal ini adalah perusahaan. Prinsip-prinsip GCG yang diterapkan yaitu transparansi, akuntabilitas, responsibiltas, independensi, dan fairness menjadikan indikator bagi perusahaan untuk mengukur tingkat keberhasilan penge-lolaan perusahaan. Disisi lain kualitas pelayanan diiukur dari indikator kemampuan petugas layanan, otoritas dan tanggung jawab, disiplin kerja serta inisiatif petugas. Untuk itu penelitian ini akan mengukur apakah penerapan prinsip GCG sudah ada di bank BTPN. Apakah penerapan prinsip GCG tersebut sejalan dengan peningkatan kualitas pelayanan terhadap nasabahnya atau sebaliknya tidak ada pengaruh antara penerapan GCG dengan kualitas pelayanan di Bank BTPN.

\section{TINJAUAN PUSTAKA}

\section{Good Corporate Governance (GCG)}

Pada April 1998, Organization for Economic Cooperation and Development (OECD) telah mengeluarkan seperangkat prinsip good corporate governance yang dikembangkan secara universal. Hal ini mengingat bahwa prinsip ini disusun untuk digunakan sebagai referensi di berbagai 
negara yang mempunyai karakteristik sistem hukum, budaya, dan lingkungan yang berbeda. Dengan demikian, prinsip yang universal tersebut akan dapat menjadi pedoman untuk semua negara atau perusahaan namun diselaraskan dengan sistem hukum, aturan, atau nilai yang berlaku di negara masing-masing. Adapun prinsip-prinsip tersebut adalah sebagai berikut : (1) Fairness (Kewajaraan dan Kesetaraan) Menjamin perlin-dungan hakhak pemegang saham, termasuk hak-hak pemegang saham minoritas dan para pemegang saham asing, serta menjamin terlaksananya komitmen para investor. (2) Transparency (Transparansi) Mewajibkan adanya suatu informasi yang terbuka, tepat waktu, serta jelas dan dapat diperbandingkan yang menyangkut keadaan keuangan, pengelolaan perusahaan dan kepemilikan perusahaan.

Accountability

(Akuntabilitas) Menjelaskan peran dan tanggung jawab, serta mendukung usaha untuk menjamin penyeimbangan kepentingan manajemen dan pemegang saham, sebagaimana yang diawasi oleh dewan komisaris. (4) Responsibility (Pertanggungjawaban) Memastikan dipatuhinya peraturan serta ketentuan yang berlaku sebagai cermin dipatuhinya nilainilai sosial. (OECD, Business Sector Advisory Group on Corporate governance, 1998).

\section{Kualitas Pelayanan}

Menurut Parasuraman (1985) yang memperkenalkan konsep Service Quality (Servqual) secara ringkas menyatakan bahwa kualitas pelayanan merupakan fungsi harapan pelanggan pada tahap pra pembelian, proses penyediaan kualitas yang diterima dan kualitas output yang diterima. Parasuraman et al. (1985) mendefinisikan kualitas pelayanan (servqual) sebagai suatu konsep yang secara tepat mewakili inti kinerja suatu jasa, yaitu perbandingan terhadap keterandalan (excellence) dalam service counter yang dilakukan oleh pelanggan.(Juzan Tri Hartanto. 2010)

Penelitian lanjutan yang dilakukan oleh Parasuraman (1988) seperti dikutip oleh Juzan Tri Hartanto (2010) menyatakan bahwa kualitas pelayanan secara umum dapat dibentuk oleh lima dimensi yaitu: (1) Keterwujudan (tangible), meru-pakan dimensi pelayanan yang menitikberatkan pada elemen-elemen yang mewakili pelayanan secara fisik. (2) Kehandalan (reliability), meru-pakan kemampuan untuk mem-berikan jasa sebagaimana yang dijanjikan secara akurat. (3) Daya tangkap (responsiveness), yaitu dimensi kualitas pelayanan yang menitik beratkan pada kemampuan untuk menghargai kepercayaan dan kerahasiaan. (4) Jaminan (assurance), merupakan keinginan untuk membantu pelanggan dan menyediakan pelayanan yang dibutuhkan. Dimensi ini menitikberatkan 
pada perilaku personel jasa untuk perhatian terhadap pelanggan. (5) Empati (empathy). Merupakan aspek yang menekankan pelayanan pelanggan sebagai seorang individu.

\section{Islam dan Good Corporate Governance}

Sebutan Good Corporate Governance merupakan sebutan baru baik bagi ilmu maupun agama manapun termasuk ajaran Islam yang telah muncul sebelum kehidupan modern. Karena terciptanya sebutan itu terjadi dalam kehidupan modern ini. Namun nilai, isi, dan tujuan Good Corporate Governance telah dibicarakan dalam Alqur'an dan Hadis. Namun pembicaraan sumber-sumber Islam itu tentu saja tidak terhimpun menjadi satu, akan tetapi seperti dalam Alqur'an terpencar-pencar. Meskipun begitu, ajaran moral Alqur'an yang berpencar-pencar itu tidak saling bertentangan satu sama lain melainkan saling menjelaskan dan mendukung. Meskipun istilah corporate governance masih baru tetapi konsepnya terdapat dalam ajaran Islam yaitu di dalam al-Qur'an dan Hadis. Al-Quran dalam surar Al Baqarah: 282-283, tentang proses transaksi secara bertahap. Ayat ini menerangkan mengenai arti pentingnya menjaga catatan secara tepat sehingga tidak ada pihak yang mendapatkan perlakuan ketidakadilan. Pelajaran dari ayat ini adalah dibutuhkannya transparancy dan disclosure dalam perjanjian bisnis. Kedua hal itu merupakan prinsip pokok yang penting bagi corporate governance kontemporer.

Dalam Alqur'an, tindakan adalah lebih penting daripada sekedar kata-kata ceramah, jargon, atau ajaran seperti ayat yang artinya mengapa kamu mengatakan apa yang tidak kamu kerjakan? Good Corporate Governance harus diwujudkan melalui tindakan dan perbuatan nyata. Karena hanya ketika tindakan itu terlihat lebih kuat dari pada pengetahuannya, maka budaya good corporate akan benar-benar melindungi Semua stakeholders (pemegang amanah) yang ada di seluruh dunia perusahaan bisnis. Terdapat beberapa hal yang sangat berkaitan erat dengan konsep corporate governance, yaitu khilafah, accountability, reliability, transparency dan juga trustworthiness, balance sheets, religious audit, dan syura. Konsep itu berasal dari pandangan dunia Islam.

Dari telaah literatur yang dijelaskan pada bagian di atas, penelitian ini akan mengambil simpulan sementara sebagai hipotesis sebagai arah penelitian ini, yaitu: H1: Terdapat pengaruh GCG terhadap kualitas pelayanan. H2: Transparansi mengukur GCG secara signifikan. H3:Akuntabilitas mengukur GCG secara signifikan. H4: Responsibilitas mengukur GCG secara signifikan. H5: Independensi mengukur GCG secara signifikan. H6: Fairness mengukur GCG secara signifikan. H7: Tangible mengukur kualitas pelayanan 
secara signifikan. H8: Reliability mengukur kualitas pelayanan secara signifikan. H9: Responsiveness mengukur kualitas pelayanan secara signifikan. H10: Assurance mengukur kualitas pelayanan secara signifikan. H11: Emphaty mengukur kualitas pelayanan secara signifikan.

Berdasarkan tinjuan pustaka dan penelitian terdahulu yang sudah diuraikan, kerangka pemikiran ini dapat diuraikan sebagai berikut:

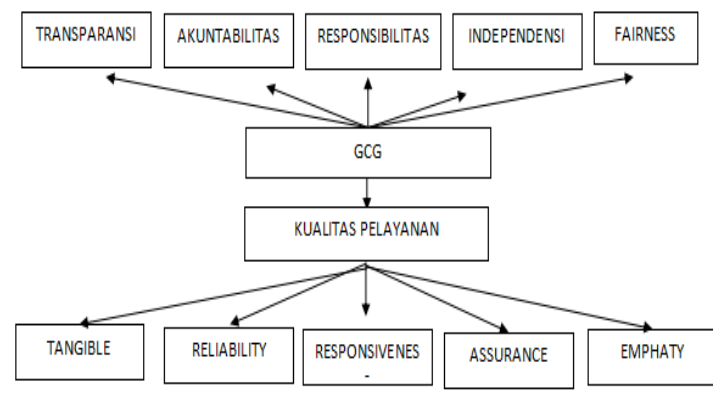

Sumber: Dikembangkan dari justifikasi penelitian terdahulu

\section{METODE}

\section{Populasi dan Sampel}

Populasi dalam penelitian ini adalah nasabah Bank BTPN yang berada di Kantor Cabang Padang. Terdapat 6.034 orang nasabah berdasarkan data nominatif bank BTPN tahun 2013 untuk nasabah bisnis pensiun. Sampel yang digunakan dalam penelitian ini adalah nasabah yang paling mudah dijumpai atau diakses dan merupakan pelanggan Bank BTPN. Teknik pengambilan sampel yaitu non probability sampling dilakukan secara accidental sampling. Jumlah nasabah yang dijadikan sampel yaitu 100 orang nasabah.

\section{PEMBAHASAN}

\section{Uji Validitas}

Adapun hasil perhitungan validas dari masing-masing variabel dengan menggunakan komputer program SPSS dapat dilihat pada tabel berikut ini:

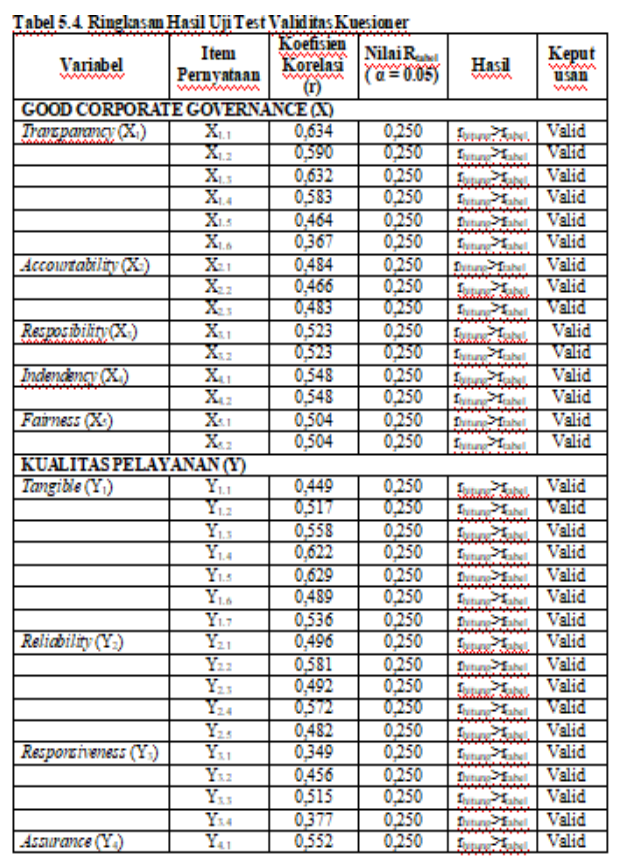

Instrumen dikatakan valid jika korelasi Product Moment menunjukkan korelasi yang signifikan antara skor item dengan skor total atau dengan cara membandingkan nilai korelasi masingmasing item dengan nilai korelasi tabel $\left(\mathrm{r}_{\text {tabel }}\right)$; Jika $\mathrm{r}$ product moment $>\mathrm{r}_{\text {tabel }}$ maka instrumen dikatakan valid. Tabel menunjukkan bahwa butir pertanyaan mempunyai nilai korelasi yang lebih besar dari $r_{\text {tabel }}$ (lebih besar dari 0,250) sehingga butir pertanyaan yang diajukan dinyatakan valid dan layak dianalisis. 


\section{Uji Reliabilitas}

Reliabilitas adalah alat untuk mengukur suatu kesioner yang merupakan indikator dari variabel atau konstruk. Pengukuran yang memiliki reliabilitas tinggi yaitu yang mampu memberikan hasil ukur yang terpercaya. Pada penelitian ini digunakan reabilitas model Cronbach's Alpha.

\begin{tabular}{|c|c|c|}
\hline Tariabel & Croubach's Alpha & Keterangm \\
\hline$X_{1}$ & 0,790 & Reliabe \\
\hline $\mathrm{X}_{2}$ & 0,056 & Relisol \\
\hline $\mathrm{X}$ & 0,686 & Religbel \\
\hline $\mathrm{X}_{\mathrm{I}}$ & 0,691 & Relisbel \\
\hline $\bar{X}$ & 0,664 & Religbel \\
\hline $\mathrm{Y}_{1}$ & 0,804 & Religbe \\
\hline $\mathrm{Y}_{2}$ & 0,757 & Religbel \\
\hline $\mathrm{Y}_{3}$ & 0,642 & Reliabel \\
\hline$Y_{4}$ & 0,710 & Relisbel \\
\hline $\mathrm{Y}_{1}$ & 0,744 & Relisbe \\
\hline
\end{tabular}

Hasil uji reliabilitas yang disajikan pada tabel di atas menunjukkan bahwa masing-masing nilai koefisien reliabilitas adalah 0,6 atau lebih, sehingga intrumen yang digunakan dinyatakan reliabel.

Berikut ini akan disajikan distribusi frekuensi item atau variabel serta rata-rata skor item yang diperoleh dari penyebaran 100 kuesioner.

\begin{tabular}{|c|c|c|c|c|c|}
\hline Vriabel & $\mathrm{N}$ & \begin{tabular}{|l|l} 
Minimm \\
\end{tabular} & Maximum & Mean & Stddervisa \\
\hline \multicolumn{6}{|c|}{ Good Corporate Governance $(\mathrm{X})$} \\
\hline Transprangey $(X)$ & 100 & 3,910 & 4,140 & 4,033 & 3,895 \\
\hline Accolutiobitiv $(\mathrm{X})$ & 100 & 4,240 & 4,310 & 4,277 & 2,040 \\
\hline Resporiblity $(X)$ & 100 & 3.870 & 3890 & 3880 & 1,949 \\
\hline Independery $(\mathrm{X})$ & 100 & 4,150 & 4,410 & 4280 & 1.839 \\
\hline Faimess $(X)$ & 100 & 4,170 & 4,210 & 4,190 & 1.625 \\
\hline \multicolumn{6}{|l|}{ Kualitas Layaanau (Y) } \\
\hline Tagitbe $(?)$ & 100 & 3,930 & 4,260 & 4,149 & 4,285 \\
\hline Reliabilit $\left(\mathrm{Y}_{2}\right)$ & 100 & 4,170 & 4,350 & 4,246 & 3,055 \\
\hline Responstiveness $\left(Y_{5}\right)$ & 100 & 4,100 & 4,290 & 4,173 & 2,219 \\
\hline Assidonce $\left(Y_{i}\right)$ & 100 & 3,960 & 4,010 & 3,985 & 2,134 \\
\hline Emphav $\left(\mathrm{Y}_{2}\right)$ & 100 & 3,690 & 4,180 & 4,027 & 4,187 \\
\hline
\end{tabular}

Berdasarkan tabel di atas untuk variable Good Corporate Governance (X) dapat diketahui bahwa Transparancy memiliki nilai minimum sebesar 3,910, nilai maksimum sebesar 4,140, rata-rata sebesar 4,033, dan standar deviasi sebesar 3,895; dan Accountability memiliki nilai minimum sebesar 4,240, nilai maksimum sebesar 4,310 , rata-rata sebesar 4,277, dan standar deviasi sebesar 2,040; dan Responsibility memiliki nilai minimum sebesar 3,870, nilai maksimum sebesar 3,890, rata-rata sebesar 3,880, dan standar deviasi sebesar 1,949; dan Independency memiliki nilai minimum sebesar 4,150, nilai maksimum sebesar 4,410, rata-rata sebesar 4,280, dan standar deviasi sebesar 1,839; dan Fairness memiliki nilai minimum sebesar 4,170, nilai maksimum sebesar 4,210, rata-rata sebesar 4,190, dan standar deviasi sebesar 1,625.

Selanjutnya untuk variable Kualitas Layanan (Y) dari tabel di atas dapat diketahui bahwa Tangible memiliki nilai minimum sebesar 3,930, nilai maksimum sebesar 4,260 , rata-rata sebesar 4,149, dan standar 
deviasi sebesar 4,285; dan Reliability memiliki nilai minimum sebesar 4,170, nilai maksimum sebesar 4,350, rata-rata sebesar 4,246, dan standar deviasi sebesar 3,055; dan Responsiveness memiliki nilai minimum sebesar 4,100, nilai maksimum sebesar 4,290, rata-rata sebesar 4,173, dan standar deviasi sebesar 2,219; dan Assurance memiliki nilai minimum sebesar 3,960, nilai maksimum sebesar 4,010, rata-rata sebesar 3,985, dan standar deviasi sebesar 2,134; dan Emphaty memiliki nilai minimum sebesar 3,690 , nilai maksimum sebesar 4,180 , ratarata sebesar 4,027, dan standar deviasi sebesar 4,187.

\section{Analisis Regresi Linear Sederhana}

Analisis regresi sederhana digunakan untuk mengetahui besarnya pengaruh variabel Good Corporate Governance (X) terhadap Kualitas Pelayanan Bank BTPN Cabang Padang. Adapun hasil perhitungan dengan menggunakan SPSS (Statistical Product Service Solution) disajikan dalam tabel berikut:

\begin{tabular}{|c|c|c|c|c|}
\hline \multicolumn{5}{|c|}{ 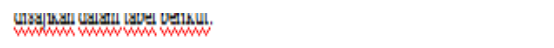 } \\
\hline Tariabel & Keterangon & $\begin{array}{l}\text { Koficisiensi } \\
\text { kegresi } \\
\text { Regi }\end{array}$ & $T_{\text {tax }}$ & $\mathrm{Sig}$ \\
\hline $\bar{X}$ & $\begin{array}{l}\text { Good Caponter } \\
\text { Governaure }\end{array}$ & 2,413 & 19,719 & 0,000 \\
\hline 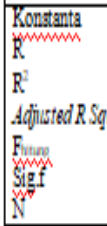 & & & $\begin{array}{c}29,099 \\
0,894 \\
0,799 \\
0,797 \\
388,821 \\
0,000 \\
100\end{array}$ & \\
\hline \multicolumn{5}{|c|}{ 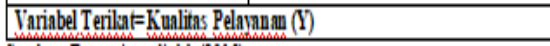 } \\
\hline
\end{tabular}

Sumber: Data primar dioloh (2015)
Dengan hasil perhitungan regresi di atas dapat diketahui formulasinya sebagai berikut:

$\mathrm{Y}=\mathrm{a}+\beta \mathrm{X}+\mathrm{e}$

$\mathrm{Y}=29,099+2,413 \mathrm{X}+\mathrm{e}$

Berdasarkan persamaan tersebut, maka dapat dijelaskan sebagai berikut :

$\mathrm{a}=29,099$ Menyatakan bahwa jika tidak ada perubahan variabel Good Corporate Governance (X), maka Kualitas Pelayanan (Y) sudah ada sebesar 29,099 satuan.

$\beta=$ Koefisien regresi Good Corporate Governance (X) sebesar 2,413 menunjukkan besarnya Good Corporate Governance (X) terhadap Kualitas Pelayanan (Y), Koefisien bertanda positif menunjukkan Good Corporate Governance (X) berpengaruh searah terhadap Kualitas Pelayanan (Y), yang berarti setiap kenaikan 1 satuan variabel Good Corporate Governance (X) akan menyebabkan pengaruh peningkatan Kualitas Pelayanan (Y) sebesar 2,413 .

Selanjutnya koefisien korelasi berganda (R) sebesar 0,894, menunjukkan bahwa variabel Good Corporate Governance (X) memiliki korelasi yang kuat dan searah terhadap Kualitas Pelayanan (Y) sebesar $89,4 \%$. Korelasi ini dapat dikategorikan sangat kuat, karena korelasi dikatakan kuat jika koefisien korelasinya mendekati atau mencapai $100 \%$ atau angka 1 (baik dengan angka positif atau negatif).

Berdasarkan hasil analisis regresi diperoleh koefisiensi determinasi R Square sebesar 0,799. Besarnya pengaruh variabel bebas terhadap variabel terikat adalah sebesar 79,9\%, sedangkan sisanya sebesar 
20,1\% merupakan faktor lain yang tidak diteliti. Nilai koefisien determinasi tersebut menunjukkan kuatnya pengaruh variabel bebas terhadap variabel terikat.

\section{KESIMPULAN}

\section{Good Corporate Governance (GCG)}

(X) berpengaruh signifikan terhadap Kualitas Pelayanan Bank BTPN Cabang Padang (Y). Kontribusi Good Corporate Governance (X) terhadap Kualitas Pelayanan Bank BTPN Cabang Padang (Y) adalah sebesar 79,9\% dan ditemukan berpengaruh signifikan, sedangkan sisanya sebesar 20,1\% merupakan faktor lain yang tidak diteliti. Semua dimensi Good Corporate Governance meliputi transparancy, accountability, respo-nsibility, independency dan fairness ditemukan memiliki korelasi yang kuat dengan va-riabel Good Corporate Gover-nance (X), dan signifikan. Dimensi yang paling kuat korelasinya yaitu Transparancy dengan nilai korelasi 0,896. Semua dimensi kualitas pelayanan meliputi tangible, reliability, responsiveness, assurance, dan empathy ditemukan memiliki korelasi yang kuat dengan variabel Kualitas Pelayanan (Y), dan signifikan. Dimensi yang paling kuat korelasinya yaitu Reliability dengan nilai korelasi 0,900.

Dalam upaya meningkatkan Kualitas Pelayanan Bank BTPN Cabang Padang maka perlu ditingkatkan Good Corporate Governance. Hal ini disebabkan variabel tersebut berpengaruh positif dan signifikan terhadap Kualitas Pelayanan Bank BTPN Cabang Padang. Dalam rangka meningkatkan Good Corporate Governance, perlu diimplementasikan dengan optimal semua dimensi Good Corporate Governance, karena terbukti semua dimensi berkorelasi signifikan dengan Good Corporate Governance. Terutama dimensi Transparancy perlu dipertahankan sebab merupakan yang paling tinggi

\section{DAFTAR PUSTAKA}

Corporate Communication Bank btpn, (BTPN)Info, Sent by email Monday, November 18,2013 4:51 PM, to \#\#BTPN Group (All), Subject Fokus Info-18 November 2013.

Denzim, N. K. \& Lincoln, Y. S. (2009). Handbook Of Qualitative Research. Yogyakarta: Pustaka Pelajar.

Ferlinda, E. D., Ribawanto, H. \& Siswidiyanto. (2010). Implementasi Good Corporate Governance Dalam Meningkatkan Kualitas Pelayanan (Studi pada PT Telkom Banyuwangi). Jurnal Admnistrasi Publik 1(4). 22-30. Fakultas Ilmu Administrasi Universitas Brawijaya Malang.

Hartanto, J. T. (2010). Analisis pengaruh Kualitas Pelayanan Jasa Perbankan terhadap Kepuasaan Nasabah (Study Kasus Pada Bank BPR Jogja). Jurnal Magister Manajemen Universitas Gunadarma. www.gunadarma.ac.id. Diakses pada 16 Mei 2014, Pukul 19.45 WIB.

Iberdrola Company. (2013) .Good Corporate Governance. www.iberdrola.es/..../gobierno. diakses 9 April 2014 jam 14.10 Wib.

Kepmenpan No 63/KEP/M.PAN/7/2003 tentang Pelayanan Publik. 
Elibrary.ub.ac.id/handle/, diakses 18 April 2014 Pukul 13.30.

Laporan Tahunan. (2010). Pelaksanaan Tata Kelola Perusahaan BTPN.

Moleong, L. J. (1995). Metodologi Penelitian Kualitatif. Bandung: PT Remaja Rosdakarya.

Pedoman Penerapan Good Corporate Governance (GCG) di Lingkungan PT Pindad (Persero)

Pedoman Umum Good Corporate Governance Indonesia Oleh Komite Nasional Kebijakan Governance Tahun 2012.

Persada, G. \& Harrison, L. (2007). Metode Penelitian Politik. Jakarta: Kencana.

Prasetyo, B. \& Jannah, L. M. (2005). Metode Penelitian Kuantitatif. Jakarta: Raja Persada.

Prinsip Dasar Pedoman Good Corporate Governance Perbankan Indonesia oleh Komite Nasional Kebijakan Governance tahun 2012

Raffles. (2013). Penerapan Good Corporate Governance Dalam Kaitannya Dengan Tata Kelola dan Pengembangan Kelembagaan Perbankan. Jurnal Ilmu Hukum Fakultas Hukum Universitas Jambi.

Raharjo. (2014). Uji Autokorelasi dengan Durbin-Watson. Online. (http://www.spssindonesia.com/2014/ 02/uji-autokorelasi-dengan-durbinwatson.html) Diakses tanggal 1 September 2015.

Rakhmat, A. (2013). Good Corporate Governance (GCG) Sebagai Prinisip Implementasi Corporate Social Responsibility (CSR) (Studi Kasus Pada Community Development Center PT Telkom Malang). Jurnal/Agung-Rakhmat/FEB B/2013.
Reny, D. R. M. \& Printinah, D. (2010). Pengaruh Good Corporate Governance dan pengungkapan corporate social responsibility terhadap nilai perusahaan (Studi empiris pada perusahaan yang terdaftar di bursa efek Indonesia periode 2007-2010. Jurnal Nominal, 1(1). Fakultas Ekonomi Universitas Negeri Yogyakarta.

Sam'ani. (2008). Pengaruh Good Corporate Governance dan Leverage terhadap Kinerja Keuangan Pada Perbankan Yang terdaftar di Bursa Efek Indonesia tahun 2004-2007. Jurnal Magister Manajemen. Universitas Diponegoro.

Shil, N. C. (2008). Accounting For Good Corporate Governance. Shil, N. C. Accounting for good corporate governance. JOAAG, 3(1). Senior lecturer of Accounting, Department of Business Administration, East West University, Dhaka, Bangladesh. Email: nikhilacc@yahoo.com

Susanti, S. (2013). Pengaruh Good Corporate Governance terhadap Corporate Social Responsibility pada perusahaan cosmetics and Household. Jurnal Ilmu dan Riset Akuntansi, 1(1). Sekolah Tinggi Ilmu ekonomi Indonesia (STIESIA) Surabaya.

Wijaya, T. (2011). Cepat Menguasai SPSS 19. Yogyakarta: Cahaya Atma. 